\title{
Islamic Environment in Child Development According to the Views of Imam al-Ghazali
}

\author{
Adibah Sulaiman \\ Universiti Sains Islam Malaysia \\ Email: adibah@usim.edu.my \\ Ezad Azraai Jamsari \\ Universiti Kebangsaan Malaysia \\ Email: eajsti@gmail.com \\ Noorsafuan Che Noh \\ Universiti Kebangsaan Malaysia \\ Email: safone2448@gmail.com
}

\section{Doi:10.5901/mjss.2014.v5n29p33}

\section{Abstract}

This article critically examines the influence of Islamic environment on the growth of children. This study's objective is to examine the reciprocal relationship, be it good or adverse, between the environment and the development process of child behaviour and attitude. Another important goal is to study the views of Imam al-Ghazali concerning child development in Islamic environment. The method used in this study was content analysis. This study shows that the environment aspect plays an important role in child growth and development. Environmental factors in the context of Islam namely parents, teachers, and the surrounding are identified to have significant effect on the growth of a child.

Keywords: environment; Islam; children; education; al-Ghazali;

\section{Introduction}

Each human being will undergo changes according to the process of growth and development. Development as in a change in characteristics cannot be measured but can be observed through a characteristic different from a previous stage. In child development, the environment influences or makes a source in their physical growth through a multitude of media. The environment meant here is the influence of parents, teachers and the surrounding. A good environment is one that is based in Islam. Ibn Khaldun (2002) explained, a good environment is necessary to produce good morals (akhlaq) and good morals must occur from the self based on observation of surrounding factors which can influence the living habits. This is supported by Langgulung (1987) who has the opinion that the environment is able to impart influence on one's moral values. This shows that positive environment can shape good morals and behaviour in child growth.

\section{Definition of Child}

A child by definition is a person of young age who has not reached puberty and is incapable of making important decisions for him or herself. Child development is the process and mechanisms which act during the physical and mental growth of a baby before turning into adult. Childhood is divided into two which are early childhood and middle and late childhood. Early childhood is from when the child is a baby until 6 years old while middle and late childhood is between 7 and 12 years old. A child during middle and late childhood starts to develop inquisitive nature about the things they see and observe (Mohd Jaladin, 2010).

According to Mohd Jaladin (2002), from the perspective of psychology children are group of individuals who surpass the stage of age between 2 and 20 years and have physical emotional and spiritual characteristics which are specific and distinguishable from other development stages. Mohd Jaladin (2002) also classified child growth mainly into three stages. 
Table 1. Development Stage of Child Growth

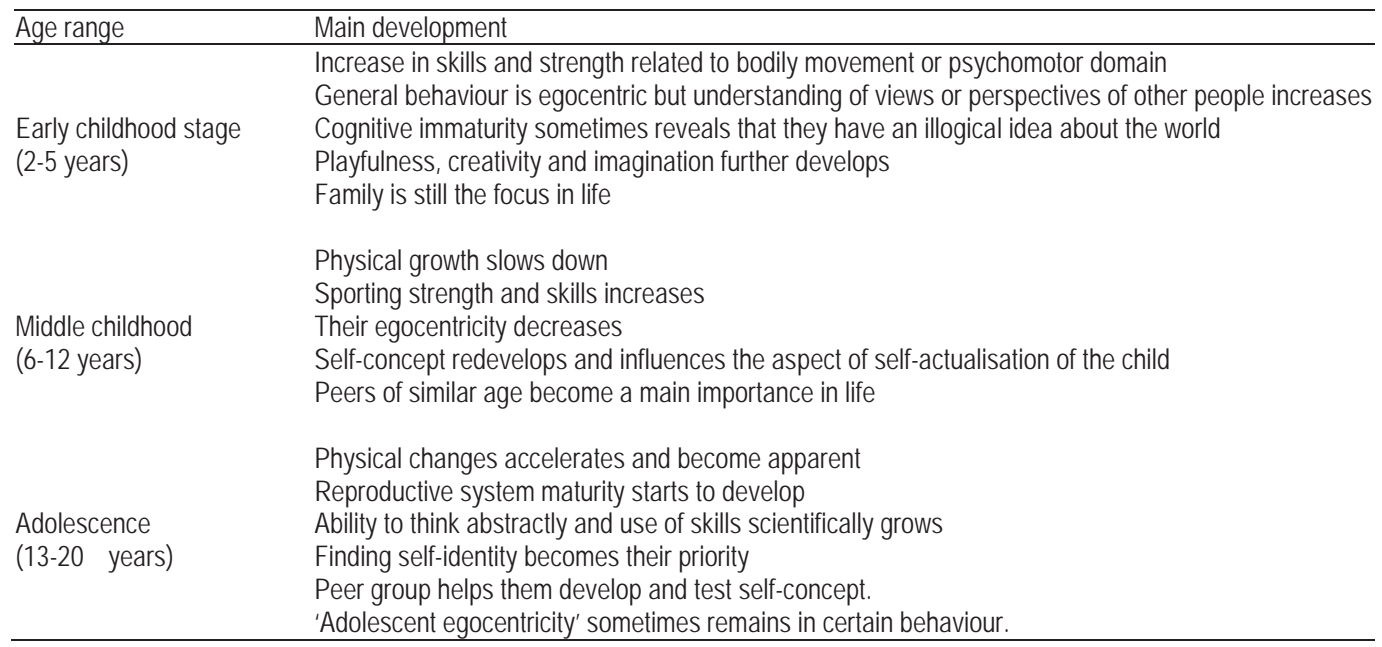

In Islam, the term 'child' refers to a person who has not reached puberty or baligh. Before children reach an age of baligh, they go through a stage of pre-mumayyiz and a stage of mumayyiz. Pre-mumayyiz stage begins from the moment a child is born until the age of seven. During that period, a child is incapable of differentiating the good from the bad and cannot comprehend the consequence of an action as well as does not have the capacity to understand. At this stage of age a child is called one who has yet to be mumayyiz (Kurshid, 1975, p. 31). The mumayyiz stage will begin when the child reaches seven or eight years of age. At that age, a different level of capability can be seen depending on the child's own self. The setting of seven years of age as the age of mumayyiz is based on a hadith narrated by 'Abd al-Malik ibn Rabi' ibn Sabrah:

\section{Meaning: Teach your children to pray when they are seven years of age and smack them (lightly) them (if they disobey) when they are ten.}

The understanding from the above hadith is that it is a command of the Messenger of Allah to parents to teach their children how to pray when they reach the age of seven. Teaching to pray cannot be done on a person who is not capable of thinking. Indirectly, the hadith infers that thinking ability is existent when a child reaches the age of seven. Therefore, a child who has reached the tamyiz thinking level is called a mumayyiz child. When children reach the age of baligh, they are considered to have thinking capability and be able to make reasonable decision on an important matter concerning them (Madkur, 1976, p. 81-82).

\section{Definition of Child Growth}

Growth is defined as an arranged and orderly change. All changes in growth will help the child in the process of reaching maturity. Children are seen to undergo change in characteristics which differ from the previous development stage. Child growth is also looked from the view of structural change, view change and the child behaviour itself. It is brought about by the function of diet, eating habit factor and the influence of the surrounding. Child growth is resultant from the actions which are inter-related between physical development and learning progress (Ismail, 2008, p. 2). Among the characteristics of child growth are (Shaari, 2009, p. 17):

a. Generally, child growth occurs stage by stage from pregnancy, infancy and childhood.

b. All children go through the same growth but at different rate.

c. The process of child growth is continuous and lasts the whole period of childhood.

d. Child growth is a change process which occurs due to actions which are inter-related between physical development and learning progress.

e. Growth is influenced by the gene factor and the environment. Gene determines the limit of development while the environment helps the development to reach a maximum level. 
f. Child growth occurs through a change in language, voice, behaviour, way of thinking, communication and others.

The level of child progress cannot be forced or controlled by their motion. A child can grow according to the level of age at a self-determined rate without compulsion to achieve the growth level. This means that the rate at which a child grows cannot be compelled if the brain, tissues and the nerves as well as the limbs are not ready to do a certain skill. Children growth is influenced by their behaviour. Therefore, parents and teachers must have the knowledge on child development psychology to assist them in child growth.

\section{Islamic Environment Which Affects Child Development}

In raising children, a good environment must be applied so that child development is assured and the child is raised to be a useful person. Each child needs a good environment so that they can learn and imitate a good culture.

\subsection{Parents}

A child is with the family since small and a major part of their time is spent with the family. Parents are the lifeblood of preparing a healthy environment for a family. Communication within the family and the brothers and sisters are also found to give an impact on parental involvement towards child upbringing at home. Impeccable upbringing will produce child of noble morals. Children are born as a test from Allah to us. As proclaimed by Allah SWT in al-Quran in Chapter al-Anfal (8: 28):

\section{Meaning: And know that your properties and your children are but a trial and that Allah has with Him a great reward.}

Allah explains in the above verse that properties and children most beloved to us are indeed a test for us. Our possession obtained in a halal manner and used for a halal cause will be rewarded by Allah. Also in this verse Allah mentioned children as a test to the believers. If children are raised following the mould of Islam, the parents will be rewarded immensely for their obedience (Sulaiman, 2008, p. 29-30).

The Messenger of Allah PBUH in one of his hadith said, which means: "educate your child 100 years before birth". This hadith carries a deep meaning due to the phrase '100 years before birth' which means long before a child is born into this world. The attitude and behaviour of parents influence the character and demeanour of a born child. The reality of educating a child in the hadith is that the folks must be educated first by doing welfare activities and refraining from doing vices (Talib, 2007, p. 77). Prior to the birth of child, parents must prepare a suitable place to raise the child as best as possible. This means to the parents that the world foremost to a child is his parents' home. To ensure completeness in child education, parents, in their domestic life, must induce an atmosphere of harmony which is characteristically Islamic. It can be done since early stage of marriage (Wan Mohd, 1990, p. 51-55).

Therefore, parents must themselves possess mahmudah virtues first and later on apply them to their children. Parents must persevere to instil good values within their children according to the following (Syahrul, 2008, p. 42-43):

a. Raise the child to obey and respect both parents by raising awareness about the great sacrifices of both parents for the children and that they need to understand and respect both of them.

b. Teach the child to speak and socialise well by training them to speak the truth, be polite and say good words. Children are very sensitive and tend to emulate what they have heard.

c. Educate the child to mix with friends. They should be reminded not to be boastful and never to hurt or take somebody else's rights.

d. Teach children bathroom etiquettes and good manners in sleeping and waking up.

In general, the process of educating a child begins from when the baby is still in the mother's womb. Tarbiah at that stage is more spiritual in nature. Children development and education are better when parents are actively and continuously involved in children education since the beginning. Parental active participation and support at this stage can increase child learning potential through continuing the learning method at home. Similar care and upbringing at care centres and at home will assist in the continuity of the learning process and will avoid confusion to the child (Stapa et al., 2012, p. 13).

\subsection{Teachers}

The process of raising a child is closely linked with the surrounding environment. Aside from parents, teacher is among 
the media having a role in helping child growth. Teachers play their role at school by giving them comprehensive education to children. They teach kids to obey and be courteous with teachers and people older than them. Kids must be made aware that teachers are the ones who are responsible to educate and deliver knowledge and should be respected and revered at all times (Abdul Nasir, 2003, p. 23). Teachers also must always show praiseworthy character to the students. The reason for this is that in the process of growing up, while at school children are easily influenced by the people around them especially teachers. Children also often make teachers their role model to follow apart from their parents. Therefore, it is only proper for teachers to show good behaviours and become role models for the students. Teachers should know the interests of children at that age to invoke the children interest in learning (Hassim et al., 2012, p. 137-140).

\subsection{Environment}

Additionally, the environment factor is one of the factors which drive the process of child growth. Should a child grow up in an atmosphere of goodness, the child development process would also run well. The same goes with the child ability. If the child grows in a less healthy environment, his development process will not run smoothly (Md. Noor, 2006, p. 41). In Islam, the environment has a role in children education so important that we are encouraged to look at the neighbourhood we live in. Children are easily influenced by their surroundings. Therefore, living in a place with a good environment is an important investment to shape children personality in becoming a good generation. The good environment meant here is not only good from the point of physical condition but also in terms of mental condition and religious way of living (Ismail et al., 2010, p. 2-3).

\section{Biography of Imam al-Ghazali}

His real name was Abu Hamid Muhammad bin Muhammad bin Ahmad al-Ghazali al-Tusi al-Shafi'i. He was born in 450AH corresponding to $1058 \mathrm{AD}$ in a village named Ghazalah in the outskirt of small fort Tus in Khurasan north of Iran. He was known as Abu Hamid for having a son named Hamid who died during infancy. Apart from that, he is more famously known as al-Ghazali. There are two opinions of historians on the use of al-Ghazali on him. Firstly, al-Ghazali is based on the name of the area of his birth which was Ghazalah. Secondly al-Ghazali refers to the daily occupation of his father as a weaver and textile merchant. This occupation is called ghazzal. Nevertheless, al-Ghazali, as named after his birthplace, is more widely used (Wahab, Undated, p. 1). Imam al-Ghazali was born in a poor family with strong hold to Islamic teachings. His father was a pious man and a good humble person, as well as a Sufi. His father was keen on knowledge and had utmost respect for learned scholars. Even though on a small income, he nevertheless raised alGhazali well during the latter's childhood hoping he would grow to become an educated person who serve for the religion. Imam al-Ghazali died on Monday on 14 Jamadilakhir 505AH/19 December 1111AD, at his birthplace at the age of 53. He successfully authored many books of various forms of knowledge. One of the famous ones was Ihya 'Ulum al-Din. Imam al-Ghazali is one of the most famous Islamic education figures among the Muslim ummah. His works are often made reference and guide in implementing matters concerning Islamic education (Wahab, Undated, p. 1-2).

\section{Views of Imam al-Ghazali on Islamic Environment in Child Development}

His view on education clarified that a child is God's gift entrusted to the parents to bring up the child and shape the heart and the mind of the child who are still pure and untainted to become a precious and valuable person. Human being is born in a state of purity and innocence. Early education is very crucial to shape the life of a person which begins with childhood. Allah SWT said in Chapter an-Nahl verse 78:

Meaning: And Allah has extracted you from the wombs of your mothers not knowing a thing, and He made for you hearing and vision and intellect that perhaps you would be grateful.

According to Shaari (2001, p. 15), child education is divided into two categories of age level, namely:

\subsection{Child of 1 until 4 Years of Age}

A child between 1 and 4 years old must be raised by a woman of friendly character and strong religious obedience. This is because parent personalities serve a strong foundation for shaping child personality. To produce children with a 
righteous heart, al-Ghazali explained, children should be taught to use good words. Apart from physical exercise and sports in order to have a healthy and fit physique, a child must be trained with courage, good manners, patience, respect for people older than him and, most especially, obedience to parents. In addition, Imam al-Ghazali added that children should be given advice, scolded once in a while and must not be frequently beaten (Md Khair, 1999, p. 34).

\subsection{Child of 5 until 7 Years of Age}

Children of 5 until 7 years of age should be taught of spiritual aspect, manners and physical exercise. Al-Ghazali had the opinion that their spiritual aspect should be exposed by means of performing prayer in full, azan (call to prayer), reciting wirid and congregational prayer. Additionally, fasting exercise should be applied to remind the child of religious education which covers both of the worldly and the hereafter. From the aspect of manners especially during mealtime with family, no one is allowed to eat before other members of the family have assembled. Washing hands is part of good table manners for cleanliness and most important is to offer prayers before eating with the right hand (Md Khair, 1999, p. 34).

The aspect of manners is part of the education for kids at home to be taught by parents and includes humbleness, truthfulness, modesty in deeds, not befriending wicked people, speaking manners and etiquettes with the elderly and parents. On the whole, they must be trained with good ways of performing prayers, fasting and differentiating between halal and haram. Imam al-Ghazali also advised that, in giving education to children, they must be taught since birth. Also, the parents must be strict with children, must not let them be pampered too much and should not be excessive in punishing children. Parents should not utter unpleasant words in front of them, ridicule them or cause their hatred (Asari, 1999, p. 12).

In one of the views of Imam al-Ghazali on child upbringing, it is encouraged to let children play as it can help in their physical development and strengthen their mind. Apart from them being naturally playful, playing can assist in bringing joy and rest to them after exhaustion from learning. Imam al-Ghazali emphasised that children must be (Stapa et al., 2012, p. 155-156):

a. Educated since birth and taught to recognise letters, write and read.

b. Given religious education based on al-Quran and Hadith to form a virtuous personality.

c. Trained with physical exercise (strong body, intelligent mind and avoid laziness).

d. Trained to practise fine manners and good habit.

e. Trained to have courage, humbleness, patience and respect for the elderly as well as obedience to parents.

f. Given advice on their mistakes and scolded once in a while only so that they respect their old folks more.

g. Guided on the obligation toward religion and Islamic hukum when they are able to think and have their own mind.

h. Monitored by parents as they are easily influenced by the surrounding and societal norms.

Imam al-Ghazali also advised both parents to always enjoin their children to have a noble personality which is to have mahmudah characteristics. They must also forbid children from doing vile and dishonourable deeds which include in mazmumah characteristics. Imam al-Ghazali's advices to the teachers are:

a. To teach children according to their capability.

b. To improve children behaviour with politeness and not by retorting in anger.

c. To not expect rewards but should show exemplary model of good behaviour.

Imam al-Ghazali also explained that socialising with pious men can shape morals of a child. Mixing with good men is one of the methods to nurture virtuous akhlaq within a child. This is because a person naturally emulates whereby he obtains both good and bad qualities from the state of other people. If a person mingles with a good person for a certain period of time, he will obtain in himself goodness from the good person and learn a lot from him without realising it (Md Khair, 1999, p. 22-23).

\section{The Importance of Education in Shaping Children}

Education is an important matter which forms the basis for one's life direction. The upbringing received by a person surely will shape his way of thinking and behaviour. Education therefore is an aspect which is important and must be given special attention so that the person can be moulded into a human as best as possible. Education or tarbiyyah in Arabic is an element that involves not only physical aspect but also emphasises on others such as spiritual aspect and the mind. It is an intricate combination of these elements within the person which would later give an impact on his behaviour and deeds (Bharom, 2006, p. 74). The Malay society is well-known for its proverb "melentur buluh biarlah dari rebungnya" or literally translated "bending bamboo must be done from its shoot". The proverb refers to the need for education process 
to begin as early as possible. Likened to young bamboo shoots, if bent or flexed it will grow conforming to the shape which has been chosen. However if bamboo shoot is let to age and grow fully, surely it is difficult to bend as the cane or rod has hardened. If it is forced or pressed excessively it may break or snap (Hashim \& Abdul Rahman, 2014, p. 18).

The same goes with education which must be applied to children. They must be taught since small. The correct upbringing will yield a competitive generation with a strong and formidable identity. Children are God's gift and trust to persons called parents. Any child is born in sacred and pure nature, free from any filth. It is therefore the responsibility of the parents to shape them and give proper education to them. It is this familial affection which actually makes the education more effective as the child is very close to the parents and is always with them. There are numerous verses in the Qur'an which guide parents on how to reprimand and advise children in giving a solid education to them to build a good personality and character of the child (Wan Jusoh, 2011, p. 10).

In ensuring effective child education, it is of utmost importance to pay attention to a process of education which consists of two processes which are teaching and learning. Teaching process is done by the teacher to provide them with various knowledge employing teaching methods which can help achieve the goals of education. The learning process meanwhile is a task for the learner himself which includes physical activities in order to attain all the new knowledge and experience. In teaching process therefore there is a good cooperation between the role of the teacher and that of the student.

\section{Conclusion}

All children are born with various potentials which will grow if given the right stimulation. To bring up and guide a child so that they have a noble personality is not an easy task. The development of a child mind for example is very much dependent upon the influence of environment in early development of the child. An earnest and intensive effort to strengthen human capital beginning from child groups must be generated from an education system which is wellplanned and systematic because the nation requires its citizens to be well-educated with decent morals and excellent work ethics. Should these factors not be readied at the specific times, child development may not occur. Income and social status affect child performance at school less, as compared to the action of families who prepare a home environment conducive for learning. Mothers should get involved in children education be it at school or in society. Parents and teachers as well as anyone who is involved in teaching and learning of children should set a high yet realistic expectation of the achievement and the kid's future. Apart from never to give up, they are recommended to discharge that duty continuously until it produces results. Therefore, giving religious and moral education to children since a tender age is a crucial duty and responsibility to carry out. Moreover, that duty and responsibility is a continuation of the practice of the Prophets and apostles of Allah.

\section{Acknowledgement}

This study is financed by the Research Grant USIM/RAGS/PPT/ULUM/36/51912, USIM; the Research Group of Arabic Culture and Islamic Civilization (KUKAPI, DPP-2014-068), UKM; the Action/Strategic Research Project (PTS-2012-061; PTS-2014-068), UKM; the University-Industry Incentive Grant (SAKTI: INDUSTRI-2012-006), UKM; and the Arus Perdana Project (AP-2012-001; AP-2013-017; AP-2014-006), UKM.

\section{References}

Abdul Nasir, G. (2003). Prinsip-prinsip Pendidikan Islam [Principles of Islamic Education]. Bentong: PTS Publications \& Distributors Sdn. Bhd.

Asari, H. (1999). Nukilan Pemikiran Klasik-Gagasan Pendidikan al-Ghazali [Classical Thoughts: al-Ghazali Education] . Yogyakarta : Tiara Wacana Yogya.

Bharom, B. (2006). Persekitaran keluarga dan kesannya terhadap tingkah laku devian remaja di daerah Pontian [Family environment and its impact on adolescent deviant behaviour in Pontian district], Master thesis. Technology University of Malaysia. Retrieved from http://eprints.utm.my/5993/1/tesis.pdf [25 Mei 2014].

al-Ghazali, Imam. (1988). Ihya Ulum al-Din. Trans. by Ismail Takub. Vol. 3. Kuala Lumpur: Victory Ajensi.

Hashim, S. \& Abdul Rahman, N.M. (2014). Pendidikan Sosioekonomi Kanak-kanak [Child Socio-economic Education]. Selangor: PTS Akademia.

Hassim, S., Tee, C., Abdul Majid, R., Mohd Jelas, Z. \& Md Yusof, H.A. (2012). Perkembangan Kecerdasan Emosi Kanak-kanak Prasekolah Bermasalah Pendengaran: Implikasinya Terhadap Penglibatan Ibu Bapa [Development of Emotional Intelligence of Hearing-impaired Pre-school Children: Its Implication on Parental Involvement]. Akademika 82(2) 2012, 137-142 (138). Retrieved 
from http://www.ukm.my/ penerbit/ akademika/acrobatakademika822/akademika [17 Mei 2014].

Ibn Khaldun. (2000). Mukaddimah Ibn Khaldun. Trans. by Dewan Bahasa dan Pustaka. Kuala Lumpur: Dewan Bahasa dan Pustaka.

Ismail, H., Alifah, A., Noor Hayati \& Hussin, M.R. (2010). Model dan Teori Perkembangan Awal Kanak-kanak [Models and Theories of Child Early Development]. Tanjung Malim: Universiti Pendidikan Sultan Idris (UPSI).

Ismail, S.Y. (2008). Perkembangan Fizikal dan Kognitif Kanak-kanak Peringkat Umur 6-12 Tahun [Physical and Cognitive Development in Children Aged 6-12 Years Old]. Retrieved from http://www.scribd.com/doc/4853347/perkembangan-fizikal-dan-kognitif-kanakkanak)[17 Mei 2014].

Langgulung, H. (1987). Asas-asas Pendidikan Islam [Foundations of Islamic Education]. Kuala Lumpur: Dewan Bahasa dan Pustaka.

Madkur, Muhammad Salam. (1976). Usul al-Figh al-Islami. Cairo: Dar al-Nahdah.

Md Khair, K.B. (1999). Falsafah dan konsep pendidikan menurut imam al-Ghazali [education philosophy and concepts according to imam al-Ghazali], Project paper. University of Malaya, Kuala Lumpur.

Md. Noor, M. (2006). Realiti dan Isu Pendidikan Awal Kanak-kanak: Masalah Pendidikan [Reality and the Issue of Early Child Education: An Education Problem]. Kuala Lumpur: Jabatan Psikologi Pendidikan dan Kaunseling, Universiti Malaya. Retrieved from http://myais.fsktm.um.edu.my/4917/1/8.pdf [ 23 Mei 2014].

Mohd Jaladin, R.A. (2010). Perkembangan kognitif kanak-kanak. Dewan Kosmik. Retrieved from http://www.academia.edu/395096/ Perkembangan_kognitif_kanak-kanak [20 Mei 2014].

Shaari, M. (2009). Memahami Ilmu Perkembangan dan Pertumbuhan Kanak-Kanak Bagi Pendidikan Berkesan [Understanding Child Development and Growth for Effective Education]. Jurnal Pendidikan Islam.

Stapa, Z., Ismail, A.M. \& Yusuf, N. (2012). Faktor Persekitaran Sosial dan Hubungannya dengan Pembentukan Jati Diri [Social Environment Factor and Its Link with Identity Formation]. Jurnal Hadhari, 155-172.

Sulaiman, S. (2008). Anak Adalah Anugerah [A Child is a Gift]. Kuala Lumpur: Utusan Publications \& Distributors Sdn Bhd.

Talib, J. (2007). Pengaruh Gaya Keibubapaan Terhadap Pencapaian Akademik Kanak-kanak. In Wacana Pengajian Umum. Bangi: Universiti Kebangsaan Malaysia.

Wan Jusoh, W.N. (2011). Metodologi Pendidikan Anak Menurut Surah Luqman [Child Education Methodology According to Chapter Luqman]. Skudai: Fakulti Pendidikan, Universiti Teknologi Malaysia.

Wahab, B. (Undated). Analisa dan bandingan pemikiran dua tokoh pendidik muslim di zaman keagungan Islam [Analysis and comparison of thoughts of two muslim educators in Islamic golden age]. Retrieved from http://www.academia.edu/4479414/ analisa_dan_bandingkan_pemikiran_duatokohpendidik_muslim[26 mei 2014]. 